\title{
A photographic survey of the epibenthic megafauna of the Arctic Laptev Sea shelf: distribution, abundance, and estimates of biomass and organic carbon demand
}

\author{
Dieter Piepenburg*, Michael K. Schmid \\ Institut für Polarökologie der Universität Kiel, Wischhofstr. 1-3, Geb. 12, D-24148 Kiel, Germany
}

\begin{abstract}
The epibenthic megafauna of the high-Arctic Laptev Sea shelf was investigated in August/September 1993 and October 1995. At 13 stations in water depths of between 14 and $45 \mathrm{~m}$, series of 5 to 29 photographs, each depicting about $1 \mathrm{~m}^{2}$ of the seabed, were taken to assess epifaunal distribution patterns and abundances. Furthermore, population biomass of dominant brittle stars was estimated by combining abundance values with size-mass relationships and size frequencies established by measuring specimens on scaled photographs. A total of 13 epibenthic species were identified. Species numbers per station were low, ranging between 1 and 6 . Total epibenthic abundances, averaging 173.7 ind. $\mathrm{m}^{-2}$, ranged considerably between 0.1 and 579.5 ind $\mathrm{m}^{-2}$ Except for some stations on shallow shelf banks $<20 \mathrm{~m}$ that were characterized by bottom-water salinities $<30$ due to fluvial dilution, the brittle star Ophiocten senceum dominated the megabenthic shelf assemblages. At the flanks of sunken Pleistocene river valleys in depths $>30 \mathrm{~m}$, it reached maximum density and biomass values of 566 ind $\mathrm{m}^{-2}$ and $1.5 \mathrm{~g}$ ash-free dry mass (AFDM) $\mathrm{m}^{2}$, respectively. At some sites, the brittle star Ophiura sarsi occurred in abundances of up to 35 ind. $\mathrm{m}^{-2}$ and attained a biomass of $3.8 \mathrm{~g} \mathrm{AFDM} \mathrm{m} \mathrm{m}^{-2}$ Of local importance were the sea cucumber Myriotrochus rinckii (up to 70 ind. $\mathrm{m}^{-2}$ ) and the bivalve Arctinula greenlandica (up to 33 ind. $\mathrm{m}^{-2}$ ). All other species were recorded with distinctly lower densities $\left(\leq 1\right.$ ind. $\left.\mathrm{m}^{-2}\right)$. Gross estimates of population respiration and production of dominant brittle stars suggest that their organic carbon demand may amount to a pooled average of about $4 \mathrm{mg} \mathrm{C} \mathrm{m}^{-2} \mathrm{~d}^{-1}$ in the Laptev Sea, locally even to a maximum of $>10 \mathrm{mg} \mathrm{C} \mathrm{m} \mathrm{m}^{-2} \mathrm{~d}^{-1}$ This finding indicates that a substantial portion of the energy flow in this high-Arctic shelf ecosystem may be channelled through dense brittle star assemblages.
\end{abstract}

KEY WORDS: Benthos A Arctic $\cdot$ Laptev Sea A Abundance Biomass $\cdot$ Carbon demand

\section{INTRODUCTION}

The Laptev Sea, one of the Arctic shelf seas north of Siberia, is among the world's least investigated regions (Thiede \& Kassens 1994). First benthos collections of Russian explorers date back to 1878 (Sirenko \& Piepenburg 1994), but more intensive studies were always severely impeded by the remoteness and the longlasting ice cover of the area (Zenkevitch 1963). Furthermore, the region was closed for western reseachers due to political reasons (Piepenburg 1995). Golikov

•E-mail: dpiepenburg@ipoe.de
(1990) and co-workers performed a first systematic sampling programme in the 1970s, mainly by scubadiving. Quantitative data on the benthic communities were, therefore, largely confined to the near-shore zone of the eastern and southeastern sea, whereas information on the vast off-shore shelf was still rather poor until the beginning of the 1990s (Petryashov 1994) when the Russian-German multidisciplinary research project 'System Laptev Sea' was initiated (Thiede \& Kassens 1994).

In the framework of this project, several field studies (TRANSDRIFT expeditions I, II and III) to the Laptev Sea were conducted in 1993, 1994 and 1995, respectively (Kassens \& Karpiy 1994, Kassens 1995, Kassens 
in press). A principal objective of the ecological research during these expeditions was to contribute to an understanding of pathways and mechanisms of the coupling between sea ice, water column and seabed in a high-latitude marine ecosystem (Knickmeier \& Schmid 1994). This aim demands, besides information on the rates of the various processes involved, a sound knowledge of the distribution and the standing stock of major elements in the various sub-systems, as estimates of abundance and biomass are essential prerequisites for any budgeting or modelling of the flow of matter and/or energy through biological systems (Lampitt et al. 1986). The benthos was, therefore, investigated with different types of gear (grabs, dredges, cameras) to adequately sample the different community fractions on various spatial scales (Knickmeier \& Schmid 1994, Petryashov 1994). Within this context, we focused on the epibenthic megafauna

The megabenthos is operationally defined as the group of benthic animals large enough to be visible on seabed photographs and to be caught by towed gear (Gage \& Tyler 1991). There is evidence that these organisms form a functional component distinct from the macro- and meiofauna (Lampitt et al. 1986). They are more important in benthic habitats than their comparatively low abundances imply, especially in foodlimited systems such as polar seas or the deep sea (e.g. Haedrich et al. 1980, Lampitt et al. 1986, Romero-Wetzel \& Gerlach 1991, Smith et al. 1993, Thurston et al. 1994, Piepenburg et al. 1995). However, only very few strictly quantitative data on megabenthic standing stock are available so far, especially for Arctic seas, because assessments are notoriously difficult (Holme \& McIntyre 1984). A combination of seabed imaging and catches of towed gear has been proposed to be most adequate for examining the epibenthic megafauna (Rice et al. 1982, Schneider et al. 1987).

In this paper, we present quantitative data on abundance and spatial distribution of the epibenthic megafauna of the Laptev Sea by applying this methodological approach. For dominant brittle stars, size frequencies were assessed and population biomass values were computed. Furthermore, their population respiration, production, and organic carbon demand was estimated by combining biomass and size data with empirical allometric functions to explore their ecological significance in this high-Arctic shelf ecosystem.

\section{MATERIAL AND METHODS}

Study area. The Laptev Sea is the smallest 1660000 $\mathrm{km}^{2}$ ) of the Eurasian-Arctic shelf seas (Zenkevitch 1963, Timokhov 1994). As typical of all high-Arctic marine systems, its biota are generally affected by low water temperatures, long-lasting ice cover (OctoberJune), and large seasonal fluctations in light regime and primary productivity (Hempel 1985). Specific properties of the Laptev Sea shelf are the shallow water depths, extending over long distances off the coastline (up to about $500 \mathrm{~km}$ ), and the strong terrestrial impact due to the seasonally strongly pulsed river discharge (Timokhov 1994). The complex seabed morphology is characterized by very shallow banks $(<20 \mathrm{~m})$ and troughs of $50 \mathrm{~m}$ depths at maximum, formed by sunken Pleistocene valleys of large Siberian rivers (Khatanga, Anabar, Olenek, Lena, Yana) flowing into the Laptev Sea (Fig. 1). The hydrography is heavily influenced by the fresh water discharge of the Siberian streams, primarily of the Lena River (about $525 \mathrm{~km}^{3} \mathrm{yr}^{-1}$; Gordeev \& Sidorov 1993). During summer, a surface layer, diluted and warmed by the abundant fluvial waters, is separated from the more saline deeper water masses (salinity $>30$ ) by a sharp halocline at about $15 \mathrm{~m}$. Due to the river discharge, sediment load is much higher in the Laptev Sea than e.g. in the Barents Sea (Timokhov 1994). Seabed properties were summarized by Lindemann (1994). The sediments of the western Laptev Sea seabed are dominated by relict delta sands. Sediment accumulation seems to be restricted to the sunken valleys of the Khatanga, Anabar and Olenek Rivers. In the eastern Laptev Sea, the seabed surface sediments are dominated by silt and clay, tracing the modern deposition areas of the sediments discharged by the Lena and Yana Rivers.

Field work. Seabed photographs were obtained during 2 expeditions to the Laptev Sea, TRANSDRIFT I with RV 'Ivan Kireyev' in August/September 1993 (Kassens \& Karpiy 1994) and TRANSDRIFT III with RV 'Kapitan Dranitsyn' in October 1995 (Kassens in press). The photo probe employed basically consisted of a vertically oriented high-resolution still camera (Photosea $^{\mathrm{rm}} 70 \mathrm{D}$ ), utilizing the $70 \mathrm{~mm}$ color slide film Kodak Ektachrome $^{\mathrm{TM}} 64$ ASA, and an oblique strobe (Photosea $\left.^{\text {TM }} 1500 \mathrm{D}\right)$. The probe was vertically lowered from the drifting ship. On seabed contact of a forerunner weight hanging about $1.5 \mathrm{~m}$ below the probe, camera and strobe were triggered and bottom contact was signalled to the operator on the ship. The probe was then heaved about $5 \mathrm{~m}$ and lowered again for the next bottom contact. This procedure was repeated several times. Thus, series of 5 to 29 non-overlapping photographs, each depicting approximately $1 \mathrm{~m}^{2}$ of the seabed, were taken along transects of about 30 to $200 \mathrm{~m}$ length at 13 stations in water depths between 14 and $45 \mathrm{~m}$ (Table 1, Fig. 1). A compass hanging below the camera at a known distance (just touching the seabed on bottom contact of the forerunner weight) was visible in most photographs and provided a size 


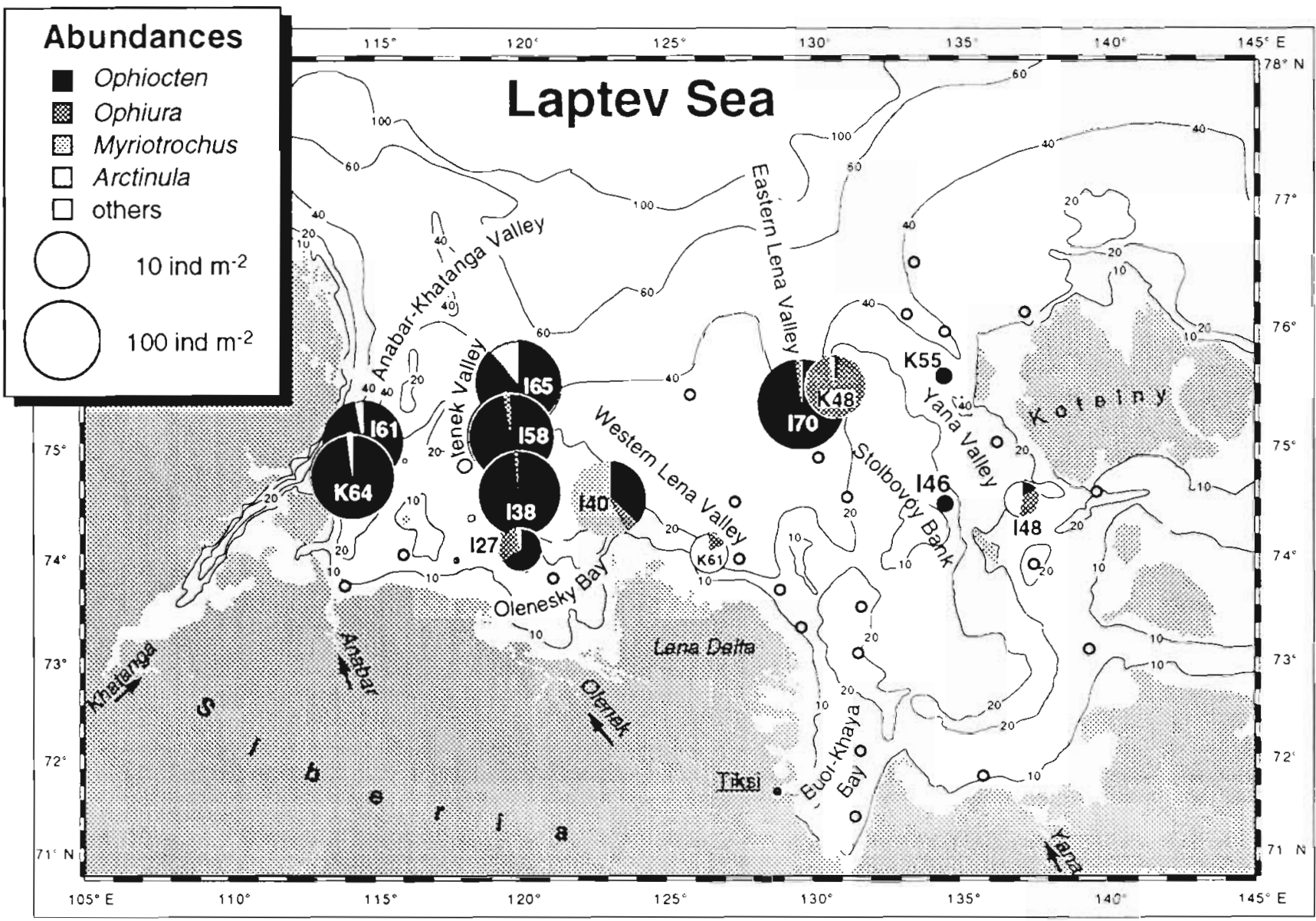

isobaths in $\mathrm{m}$

Fig. 1 Laptev Sea. Distribution, composition and standing stock of epibenthic megafauna, derived from seabed photographs taken during TRANSDRIFT expeditions I and III in August/September 1993 and October 1995, respectively. Pie sizes are logarithmically scaled according to total megabenthic abundances (ind. $\mathrm{m}^{-2}$ ), wedges depict abundance shares of dominant species, and inserted numbers denote station labels. Small open dots indicate stations from which seabed photographs could not be analyzed quantitatively because bottom water was too turbid

scale. Due to the high resolution of the optical system used, epibenthic organisms as small as $1 \mathrm{~mm}$ were identifed and are, by definition, operationally referred to as megabenthic animals. In 1993, a micro-CTD (Falmouth Inc., Caulumet, MA, USA) was attached to the probe to measure in situ temperature and salinity of the bottom water. For a detailed description of the imaging system and its operation, see Piepenburg \& von Juterzenka (1994). In addition, megabenthic animals were collected from dredge catches carried out at the same stations or at those adjacent to the imaging sites (M. K. Schmid \& V. V. Petryashov unpubl.). The cod end of the dredge had a mesh size of $10 \mathrm{~mm}$. However, at most of the stations the cod end was clogged by sediment so that smaller animals were caught as well. The specimens collected from the catches were preserved in a borax-buffered $4 \%$ formaldehyde-seawater solution for further laboratory analyses.
Data analysis. Epibenthic specimens were identified to species (or putative species) and counted on each photograph. Identifications were conducted with reference to Mortensen (1927), D'yakonov (1967), and Paterson (1985) for echinoderms, and Ockelmann (1958) and Bernard (1979) for bivalves. They were aided by the comparison with specimens collected from concomitant dredge catches and the taxonomic advice of I. S. Smirnov and V. V. Petryashov from the Zoological Institute of the Russian Academy of Sciences in St. Petersburg (Russia). Due to the resolution of the optical system used, the smallest specimens identifiable in the photographs had a body size of $1 \mathrm{~mm}$ (Piepenburg \& von Juterzenka 1994). The mean counts per station were raised to abundance figures (ind. $\mathrm{m}^{-2}$ ) using the average area covered by each photograph of a given transect.

Population biomass of 3 dominant brittle star species was estimated from the photographically derived 
Table 1 Station list. Seabed photography in the Laptev Sea during expeditions TRANSDRIFT I with RV 'Ivan Kireyev' in 1993 and TRANSDRIFT III with RV 'Kapitan Dranitsyn' in 1995. Station label, date of sampling, position (latitude, longitude, topography), water depth, bottom water temperature and salinity, dry weight percentage (\% dw) of sand and gravel (grain size $>63 \mu \mathrm{m})$ in surficial sediments (from Lindemann 1994), and number of seabed photographs are given for each station. (-) Missing values

\begin{tabular}{|c|c|c|c|c|c|c|c|c|c|}
\hline $\operatorname{Stn}$ & Date & $\begin{array}{l}\text { Lat. } \\
\text { (N) }\end{array}$ & $\begin{array}{l}\text { Long. } \\
\text { (E) }\end{array}$ & Topography & $\begin{array}{l}\text { Depth } \\
(\mathrm{m})\end{array}$ & $\begin{array}{c}\text { Temp. } \\
\left({ }^{\circ} \mathrm{C}\right)\end{array}$ & Sal. & $\begin{array}{l}\text { Sanci } \\
(\% d w)\end{array}$ & $\begin{array}{c}\text { Photos } \\
\text { (n) }\end{array}$ \\
\hline \multicolumn{10}{|c|}{ TRANSDRIFT I, 1993} \\
\hline 161 & 10 Aug & $74^{\circ} 59.7^{\prime}$ & $114^{\circ} 33.3^{\prime}$ & Anabar-Khatanga Valley & 36 & -1.6 & 34.0 & 52 & 21 \\
\hline 127 & 13 Aug & $73^{\circ} 59.5^{\prime}$ & $119^{\circ} 51.6^{\prime}$ & Olenek Valley & 30 & 1.7 & 30.0 & - & 18 \\
\hline 138 & $14 \mathrm{Aug}$ & $74^{\circ} 29.8^{\prime}$ & $119^{\circ} 58.2^{\prime}$ & Olenek Valley & 34 & 1.7 & 30.0 & 50 & 29 \\
\hline $\mathrm{I} 40$ & 15 Aug & $74^{\circ} 300^{\prime}$ & $122^{\circ} 59.6^{\prime}$ & Western Lena Valley & 15 & 2.0 & 28.0 & 97 & 10 \\
\hline $\mathrm{I} 46$ & 17 Aug & $74^{\circ} 29.7^{\prime}$ & $134^{\circ} 01.2^{\prime}$ & Stolbovoy Bank & 14 & 0.0 & 26.0 & 80 & 28 \\
\hline I 48 & 18 Aug & $74^{\circ} 29.8^{\prime}$ & $137^{\circ} 01.6^{\prime}$ & Yana Valley & 20 & 1.5 & 27.5 & 10 & 5 \\
\hline 158 & 5 Sep & $75^{\circ} 004^{\prime}$ & $119^{\circ} 51.1^{\prime}$ & Olenek Valley & 33 & 1.6 & 30.0 & 46 & 15 \\
\hline 165 & $6 \mathrm{Sep}$ & $75^{\circ} 28.9^{\prime}$ & $119^{\circ} 54.1^{\prime}$ & Olenek Valley & 45 & 1.7 & 30.0 & 68 & 5 \\
\hline 170 & 8 Sep & $75^{\circ} 18.6^{\prime}$ & $129^{\circ} 33.4^{\prime}$ & Eastern Lena Valley & 44 & 1.5 & 29.5 & 23 & 14 \\
\hline \multicolumn{10}{|c|}{ TRANSDRIFT III, 1995} \\
\hline $\mathrm{K} 48$ & $16 \mathrm{Oct}$ & $75^{\circ} 29.1^{\prime}$ & $130^{\circ} 41.6^{\prime}$ & Eastern Lena Valley & 39 & - & - & - & 15 \\
\hline K55 & $17 \mathrm{Oct}$ & $75^{\circ} 34.2^{\prime}$ & $134^{\circ} 32.5^{\prime}$ & Yana Valley & 36 & - & - & - & 20 \\
\hline K61 & $18 \mathrm{Oct}$ & $73^{\circ} 53.8^{\prime}$ & $126^{\circ} 52.4^{\prime}$ & Western Lena Valley & 23 & - & - & - & 18 \\
\hline K64 & 20 Oct & $74^{\circ} 36.8^{\prime}$ & $114^{\circ} 29.7^{\prime}$ & Anabar-Khatanga Valley & 39 & - & - & - & 26 \\
\hline
\end{tabular}

abundance values. Wet mass values were determined for 74 specimens of Ophiura sarsi, collected from dredge catches, with disc diameters ranging from 3.5 to $23.5 \mathrm{~mm}$. The values were converted to ash-free dry mass (AFDM) using a conversion factor of 0.064 $( \pm 0.002 \mathrm{SD})$ determined for 15 individuals from the Barents Sea (Schmid unpubl. data). A functional relationship between disc diameters $(d)$ and body mass $(M)$ was established $\left(M=0.0404 d^{2.762}, \mathrm{r}^{2}=0.976\right)$ using least-square regression. For the species Ophiocten sericeum and Ophiacantha bidentata, size-mass relationships determined in the Barents Sea were used (Piepenburg \& Schmid 1996a: $M=0.0465 d^{2445}$ and $M=0.1507 d^{2488}$, respectively). Furthermore, disc diameters of brittle star specimens were measured on scaled photographs from 6 stations to the nearest $\mathrm{mm}$ below (i.e. with a resolution of $1 \mathrm{~mm}$ ). Thus, it was possible to construct station-specific size frequency distributions (for all specimens $\geq 1 \mathrm{~mm}$ ) which are, in contrast to net catches, not biased by size-dependent differences in sampling efficiency. By combining mean abundance values, size frequency distributions and size-mass relationships, biomass values per size group were computed for each station and then summed up to mean biomass values per station. For stations for which no size data were available, size frequency distributions recorded at nearby stations or at those located at a similar depth were assumed to be representative. AFDM was converted to organic carbon mass using a factor of 0.5 . Spearman's rank correlation coefficient $\rho$ was used to statistically assess the relationship between biotic and abiotic parameters ( $\mathrm{Zar}$ 1984).
In a similar approach, population respiration $\left(R_{i}\right.$ in mg C m$~^{-2} \mathrm{~d}^{-1}$ ) of the 3 selected brittle stars was approximated by combining our data on station-mean abundance and size frequencies with size-dependent individual respiration rates $\left(I R_{i}\right.$ in $\left.\mathrm{mg} \mathrm{C} \mathrm{d}^{-1}\right)$. These rates were estimated for each size class by an allometric equation relating $I R$ to body mass $M\left(I R=0.007 M^{-024}\right.$; $r^{2}=0.884$ ) proposed by Mahaut et al. (1995) for deepsea benthos living at temperatures of 2 to $4^{\circ} \mathrm{C}$. Furthermore, gross estimates of somatic production $\left(P_{i}\right.$ in $\mathrm{mg} \mathrm{C}$ $\mathrm{m}^{-2} \mathrm{~d}^{-1}$ ) were derived from respiration values $R$ by assuming a size-independent net growth efficiency $K_{2}$ of $30 \%\left(=100 \times P / A\right.$, with assimilation $A=R+P_{\text {i }}$ equivalent to a ratio $P / R=3 / 7$ ). This $K_{2}$ value has been proposed as a grand average for poikilothermic wild populations (Wieser 1986, McLusky \& MacIntyre 1988). Finally, estimates of the carbon demand $(D$; in mg $C$ $\mathrm{m}^{-2} \mathrm{~d}^{-1}$ ) were computed from $A$ by assuming an average assimilation efficiency of $80 \%$ of the organic carbon in the ingested food (i.e. $D=A / 0.8$; Winberg 1960) for the primarily carnivorous brittle star species considered here (Warner 1982).

\section{RESULTS}

\section{Species composition}

Thirteen epibenthic species were recorded on 224 seabed photographs taken at 13 stations in the Laptev Sea:
Anthozoa: Alcyonaria
Gersemia sp. 


\author{
Anthozoa: Ceriantharia \\ Cerianthus sp. \\ Mollusca: Bivalvia \\ Arctinula greenlandica (Sowerby, 1842) \\ Crustacea: Isopoda \\ Saduria sp. \\ Echinodermata: Crinoidea \\ Heliometra glacialis (Owen, 1833) \\ Echinodermata: Asteroidea \\ Hymenaster pellucidus Wyville Thomson, 1873 \\ Urasterias lincki (Müller et Troschel, 1842) \\ Echinodermata: Ophiuroidea \\ Ophiacantha bidentata (Retzius, 1805) \\ Ophiura sarsi Lütken, 1855 \\ Ophiocten sericeum (Forbes, 1852) \\ Ophiopleura borealis Danielssen et Koren, 1877 \\ Echinodermata: Echinoidea \\ Strongylocentrotus sp. \\ Echinodermata: Holothuroidea \\ Myriotrochus rinkij Steenstrup, 1851
}

The sea star Urasterias lincki was recorded with only a single specimen at 1 station (K55) and was, therefore, excluded from further analyses.

\section{Species numbers}

The faunistic diversity of epibenthic assemblages, as derived from the analyses of seabed photographs, was low. Species numbers per station ranged between 1 and 6 (Table 2). In our data set, no significant relation of species numbers to water depths $(\rho=0.219, n=13$, $p=0.469)$ or bottom-water salinities $(\rho=0.563, n=9$, $p=0.137$ ) or seabed composition, parameterized by the percentage of sand and gravel (grain sizes $>63 \mu \mathrm{m}$ ) in surficial sediments $(p=-0.409, n=9, p=0.280)$, could be detected.

\section{Megabenthic abundance}

Overall, the brittle star Ophiocten sericeum was the most abundant epibenthic species (Table 2). Especially at the flanks of the sunken Pleistocene river valleys, specimens of $O$. sericeum were observed on almost every photograph. Its within-station mean abundances ranged from about 4 to 566 ind. $\mathrm{m}^{-2}$ (Table 2, Fig. 1). The distribution of the specimens along the photographic transects was, however, extremely patchy, as indicated by the high standard deviations of the means (Table 2). At some sites, the brittle star Ophiura sarsi occurred in abundances of up to 36 ind. $\mathrm{m}^{-2}$ (Table 2, Fig. 1). Of local importance were the sea cucumber Myriotrochus rinckii (Stn I40: 70 ind. $\mathrm{m}^{-2}$ ) and the bivalve Arctinula greenlandica (Stn I65: 33 ind. $\mathrm{m}^{-2}$ ). All other species were recorded in distinctly lower numbers (Table $2: \leq 1$ ind. $\mathrm{m}^{-2}$ ).

Total epibenthic abundances ranged considerably between 0.1 and 579.5 ind $\mathrm{m}^{-2}$, averaging 173.7 ind. $\mathrm{m}^{-2}$ (Table 2). A cause of this substantial variation was not discernible in our data. The values tended to increase with water depths and bottom-water salinities, but these trends were statistically not significant $(\mathrm{\rho}=0.579, \mathrm{n}=13, \mathrm{p}=0.055$ and $\rho=0.634, \mathrm{n}=9, \mathrm{p}=$ 0.093 , respectively). Likewise, no significant relation of epifaunal densities to seabed composition (i.e. sand content in surficial sediment) was observed ( $\rho=$ $-0.357, n=8, p=0.345$ )

\section{Size composition of brittle stars}

The disc diameters of Ophiocten sericeum ranged between <1 and $9.5 \mathrm{~mm}$ (Fig. 2). Along the Olenek Valley, there was a clear depth-related trend: the modes in the size frequency distributions increased from $1.5 \mathrm{~mm}$ at $30 \mathrm{~m}$ (Stn 127 ) to $6.5 \mathrm{~mm}$ at $43 \mathrm{~m}$ (Stn I65). In the Anabar-Khatanga Valley, 2 modes were conspicuous in the size distribution, one at $1.5 \mathrm{~mm}$ and the other at $5.5 \mathrm{~mm}$ (Fig. 2). In the Western and Eastern Lena Valley (Stn 140 at $16 \mathrm{~m}$ and Stn 170 at $44 \mathrm{~m}$, respectively), the size distributions were rather broad and exhibited little pronounced modes at $3.5 \mathrm{~mm}$ and $2.5 \mathrm{~mm}$, respectively.

The disc diameters of Ophiura sarsi, measured on the seabed photographs, fell into a range of 7 to $27 \mathrm{~mm}$ (Fig. 3). As for Ophiocten sericeum, a bathymetric trend was discernible: in the Olenek Valley (Stns I27, I38, I65), as well as in the Western (Stn I40) and Eastern Lena Valley (Stn I70), the modes in the size distributions increased with water depths from 11 to 17 and $19 \mathrm{~mm}$, respectively (Fig. 3).

For Ophiacantha bidentata in the Anabar-Khatanga Valley (Stn I61), disc diameters ranging from 3.5 to $11.5 \mathrm{~mm}$ with maximum abundance of between 8 and $9 \mathrm{~mm}$ were recorded (Fig. 4)

\section{Biomass, respiration, production and carbon demand of brittle stars}

Population biomass was computed for the 3 brittle star species Ophiocten sericeum, Ophiura sarsi and Ophiacantha bidentata (Table 3). The most abundant species $O$. sericeum reached maximum values of nearly $1500 \mathrm{mg}$ AFDM m $\mathrm{m}^{-2}$ (equivalent to $750 \mathrm{mg} \mathrm{C}$ $\mathrm{m}^{-2}$ ) in the Olenek Valley. Despite its lower abundances, the much larger $O$. sarsi was similarly important in terms of biomass, especially in the Eastern Lena 


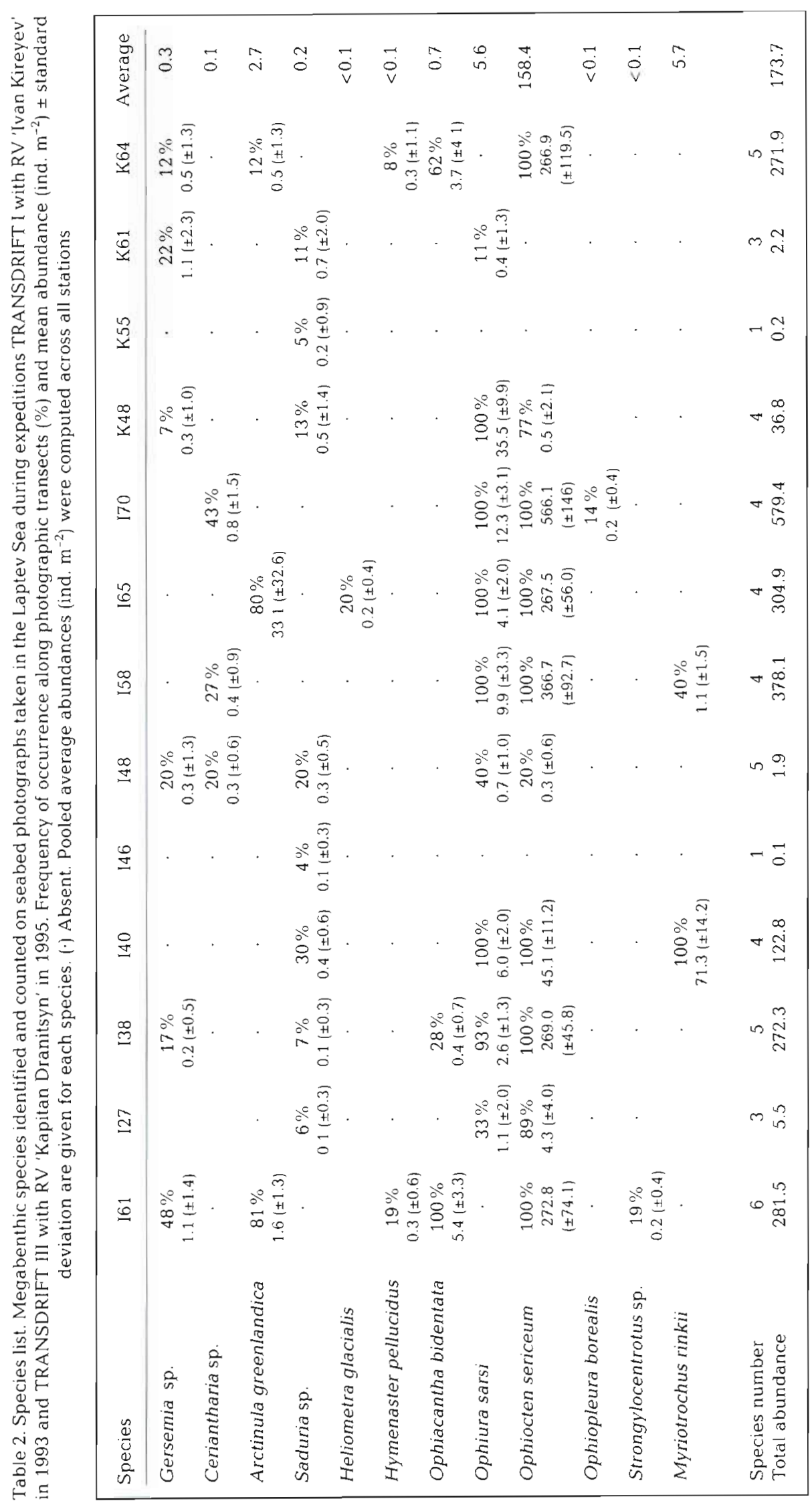


Fig. 2. Ophiocten sericeum. Size frequencies (1 $\mathrm{mm}$ disc diameter classes) of specimens measured on seabed photographs from the Laptev Sea (Stns 127, $138,165,140,161,170)$
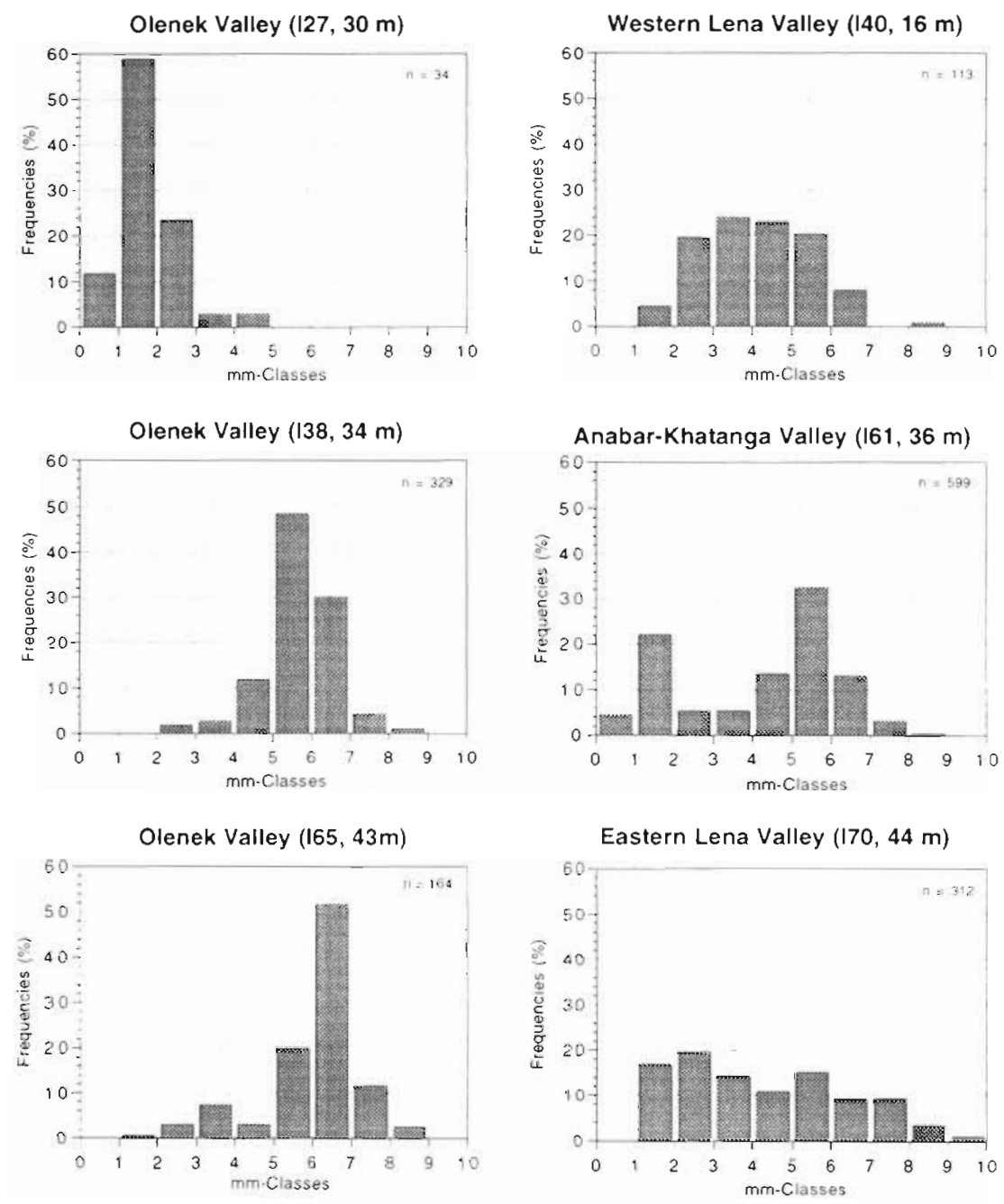

Table 3. Dominant brittle stars of the Laptev Sea. Biomass ( $\mathrm{mg} \mathrm{AFDM} \mathrm{m}^{-2}, \mathrm{mg} \mathrm{C} \mathrm{m}^{-2}$ ) of Ophiocten sericeum, Ophiura sarsi and Ophiacantha bidentata, as well as estimates of thelr total daily respiration, production and organic carbon demand (rounded to the nearest $\mathrm{mg} \mathrm{C} \mathrm{m}^{-2} \mathrm{~d}^{-1}$ ). Stations arranged according to their geographic location. (·) Absent. Average values were computed across all stations

\begin{tabular}{|c|c|c|c|c|c|c|c|c|c|c|}
\hline \multirow[t]{2}{*}{ Region } & \multirow[t]{2}{*}{ Stn } & \multirow{2}{*}{$\begin{array}{l}\text { Depth } \\
\text { (m) }\end{array}$} & $\begin{array}{l}\text { Ophiocten } \\
\text { sericeum }\end{array}$ & \multirow{2}{*}{\multicolumn{2}{|c|}{$\begin{array}{l}\text { Ophiura Ophiacantha } \\
\text { sarsi bidentata } \\
\text { AFDM m} \text { m }^{-2} \text { ) }\end{array}$}} & \multicolumn{2}{|c|}{$\begin{array}{l}\text { Total biomass } \\
\left(\mathrm{mg} \mathrm{m}^{-2}\right)\end{array}$} & \multirow{2}{*}{\multicolumn{2}{|c|}{$\begin{array}{l}\text { Respiration Production } \\
\qquad\left(\mathrm{mg} \mathrm{C} \mathrm{m}^{-2} \mathrm{~d}^{-1}\right)\end{array}$}} & \multirow{2}{*}{ C-demand } \\
\hline & & & (mg & & & AFDM & $\mathrm{C}$ & & & \\
\hline Anabar-Khatanga & 161 & 36 & 590 & & 176 & 766 & 383 & 2 & 1 & 4 \\
\hline Valley & K64 & 39 & 577 & . & 121 & 698 & 349 & 2 & 1 & 4 \\
\hline \multirow[t]{4}{*}{ Olenek Valley } & 127 & 30 & 1 & 68 & $\cdot$ & 69 & 35 & $<1$ & $<1$ & $<1$ \\
\hline & {$[38$} & 34 & 943 & 160 & 13 & 1116 & 558 & 3 & 2 & 6 \\
\hline & 158 & 33 & 1487 & 897 & $\cdot$ & 2384 & 1192 & 6 & 3 & 10 \\
\hline & I65 & 45 & 1084 & 371 & $\cdot$ & 1455 & 728 & 4 & 2 & 7 \\
\hline \multirow{2}{*}{$\begin{array}{l}\text { Western Lena } \\
\text { Valley }\end{array}$} & 140 & 15 & 81 & 258 & . & 339 & 170 & 1 & $<1$ & 1 \\
\hline & $\mathrm{K} 61$ & 23 & $\cdot$ & 17 & . & 17 & 9 & $<1$ & $<1$ & $<1$ \\
\hline \multirow{2}{*}{$\begin{array}{l}\text { Eastern Lena } \\
\text { Valley }\end{array}$} & 170 & 44 & 1325 & 1304 & . & 2629 & 1315 & 6 & 3 & 11 \\
\hline & $\mathrm{K} 48$ & 39 & 1 & 3764 & & 3765 & 1883 & 5 & 2 & 9 \\
\hline \multirow{3}{*}{$\begin{array}{l}\text { Stolbovoy Bank } \\
\text { Yana Valley }\end{array}$} & 146 & 14 & & & & 0 & 0 & 0 & 0 & 0 \\
\hline & 148 & 20 & $<1$ & 30 & & 30 & 15 & $<1$ & $<1$ & $<1$ \\
\hline & K55 & 36 & $\cdot$ & & $\cdot$ & 0 & 0 & 0 & 0 & 0 \\
\hline \multicolumn{2}{|l|}{ Pooled averages } & 31 & 469 & 528 & 24 & 1021 & 510 & 2 & 1 & 4 \\
\hline
\end{tabular}



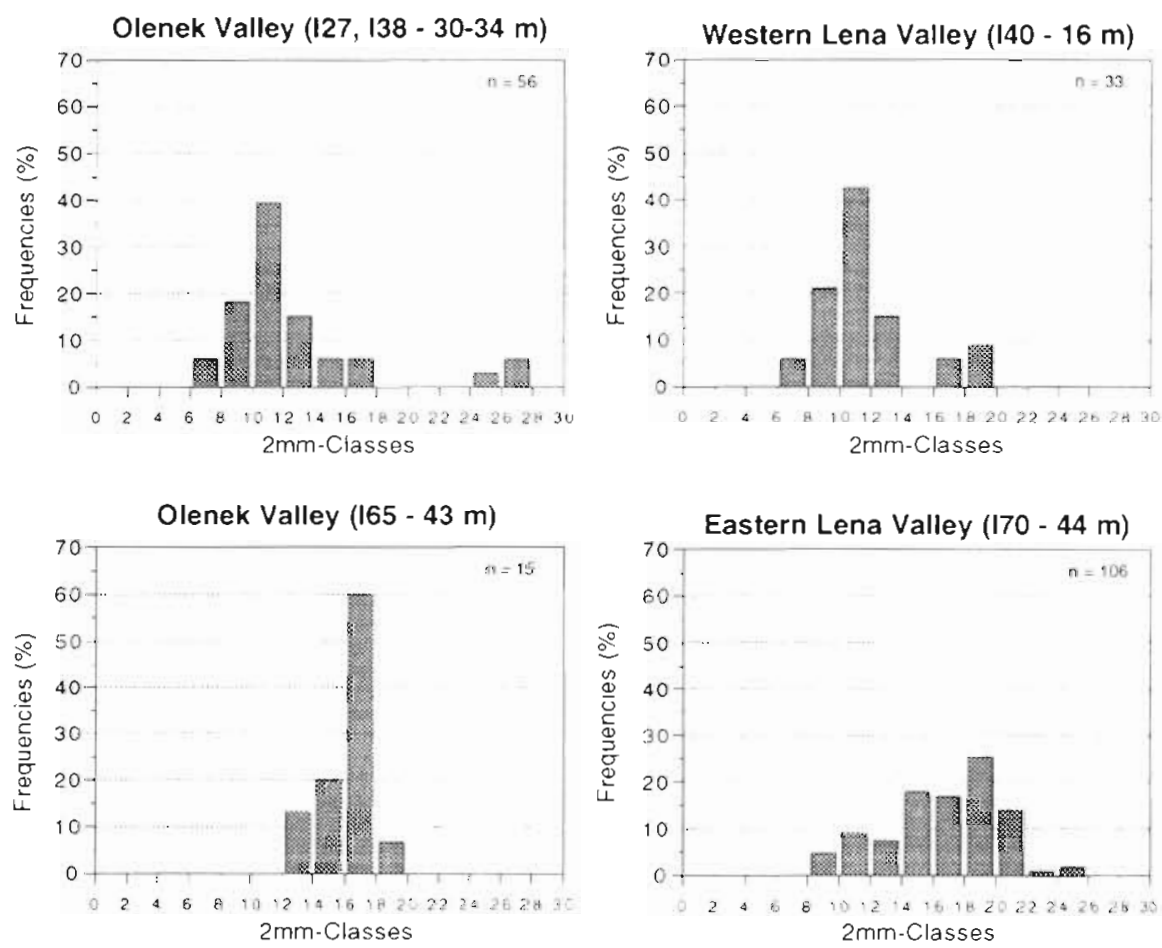

Fig. 3. Ophiura sarsi. Size frequencies ( $2 \mathrm{~mm}$ disc diameter classes) of specimens measured on seabed photographs from the Laptev Sea

(Stns 127 and I38, 165, 140, [70)

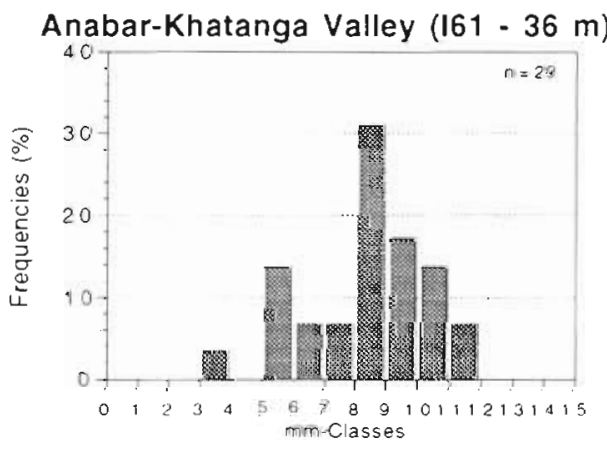

Fig. 4. Ophiacantha bidentata. Size frequency $(1 \mathrm{~mm}$ disc diameter classes) of specimens measured on seabed photographs from the Laptev Sea (Stn I61)

Valley (maximum $3764 \mathrm{mg}$ AFDM m $\mathrm{m}^{-2}=1732 \mathrm{mg} \mathrm{C}$ $\mathrm{m}^{-2}$ ). O. bidentata was distinctly less important, reaching a maximum biomass of $176 \mathrm{mg}$ AFDM m $\mathrm{m}^{-2}(88 \mathrm{mg}$ $\mathrm{C} \mathrm{m}^{-2}$ ) in the Anabar Khatanga Valley. The pooled average biomass of the 3 brittle star species in the Laptev Sea was 468,528 and $24 \mathrm{mg} \mathrm{AFDM} \mathrm{m}^{-2}$ for $O$. sericeum, $O$. sarsi and $O$. bidentata, respectively.

Total brittle star biomass in the Laptev Sea ranged from $17 \mathrm{mg} \mathrm{AFDM} \mathrm{m}{ }^{-2}$ (about $9 \mathrm{mg} \mathrm{C}^{-2}$ ) in the Western Lena Valley to $3765 \mathrm{mg} \mathrm{AFDM} \mathrm{m}^{-2}$ (about $1883 \mathrm{mg}$ $\mathrm{C} \mathrm{m}^{-2}$ ) in the Eastern Lena Valley, averaging $1021 \mathrm{mg}$ AFDM m${ }^{-2}$ (510 $\mathrm{mg} \mathrm{C} \mathrm{m}^{-2}$ ). It increased significantly with water depths $(\rho=0.636, n=13, p=0.035)$. The relations to other presumably important environmental parameters such as bottom-water salinity and seabed composition (i.e. sand content in surficial sediment) were not significant $(\rho=0.586, n=9, p=0.121$ and $\rho=$ $-0.381, \mathrm{n}=8, \mathrm{p}=0.314$ ).

Besides biomass, the total respiration, production and organic carbon demand of the 3 brittle stars Ophiocten sericeum, Ophiura sarsi and Ophiacantha bidentata were estimated (Table 3). Respiration values ranged from $<0.1 \mathrm{mg} \mathrm{C} \mathrm{m}^{-2} \mathrm{~d}^{-1}$ in the Western Lena and Yana Valleys to about $6 \mathrm{mg} \mathrm{C} \mathrm{m}^{-2} \mathrm{~d}^{-1}$ in the dense brittle star beds of the Olenek and Eastern Lena Valleys. The respiration-derived production values ranged between $<0.1$ and nearly $3 \mathrm{mg} \mathrm{C} \mathrm{m}{ }^{-2} \mathrm{~d}^{-1}$. The highest organic carbon demand of the brittle stars was estimated to be $>10 \mathrm{mg} \mathrm{C} \mathrm{m}^{-2} \mathrm{~d}^{-1}$ at the flanks of the Olenek and Eastern Lena Valleys. Pooled average values of ophiuroid daily respiration, production and carbon demand in the Laptev Sea were estimated to be 2 , 1 and $4 \mathrm{mg} \mathrm{C} \mathrm{m}{ }^{-2} \mathrm{~d}^{-1}$.

\section{DISCUSSION}

\section{Sampling}

In contrast to the investigations in the Greenland and Barents Seas (Piepenburg \& Schmid 1996a, b), most photo probe casts in the Laptev Sea (i.e. 25 out of 38) were unsuccessful. The turbidity of the bottom water was often so high that the seabed photographs taken at 
a distance of $1.4 \mathrm{~m}$ from the bottom could not be quantitatively analysed. Such high turbidities were encountered especially at sites in the western Laptev Sea (i.e. west of $125^{\circ} \mathrm{E}$ ) shallower than $25 \mathrm{~m}$, and in the eastern Laptev Sea even throughout the whole depth range covered (Fig. 1: 9 to $47 \mathrm{~m}$ ). Consequently, our sampling effort was concentrated on the relatively deep shelf valleys, and shallow shoal stations were under-represented in our data.

It may be argued that seasonal and/or interannual trends possibly biased the spatial patterns described since samples were taken in August/September and October in 2 different years (Table 1). Our admittedly rather limited data on faunistic composition, abundance and size distribution do not provide unequivocal evidence that spatial and bathymetric patchiness is more pronounced than temporal changes during the study period. The similarity in composition and abundance of 2 nearby stations (I61 and K64) in the Anabar-Khatanga Valley (Fig. 1), sampled on 10 August 1993 and 20 October 1995 (Table 1), respectively, suggests that temporal variation was not so conspicuous that it could severely mask spatial differences. In contrast, 2 stations (170 and K48) in the Eastern Lena Valley, sampled on 8 September 1993 and 16 October 1995 (Table 1), respectively, differed substantially in epifaunal composition and abundance, though they were even closer than Stns I61 and K64. It cannot be decided whether this reflects a temporal shift or rather mesoscale spatial patchiness. In general, temporal effects on the time scale of months can probably be neglected for megabenthic assemblages. It is very unlikely that community patterns changed significantly during the 4 wk sampling period of midAugust to mid-September 1993, considering the general time scale of megabenthic population dynamics in polar waters (Dayton 1990).

\section{Species composition}

Most of the megabenthic organisms recorded in our photographic survey belonged to boreal-Arctic species (Myriotrochus rinkii, Ophiocten sericeum, Ophiacantha bidentata, Ophiura sarsi), while the species classified as endemic-Arctic, such as Arctinula greenlandica, Heliometra glacialis, Ophiopleura borealis and Hymenaster pellucidus, were less abundant (Ockelmann 1958, Smirnov 1994). It should be noted, however, that the taxonomic status of some geographically and bathymetrically widely distributed boreal-Arctic species is still being discussed. $O$. bidentata occurring on Arctic shelves, for instance, may not belong to the same species as the specimens inhabiting the North Atlantic deep sea because they differ in their reproduction modes: while the Arctic animals are gonochoric, the Atlantic ones have been shown to be protandric hermaphrodites (Tyler \& Gage 1982). For more information on the general zoogeographic and bathymetric distribution of the species, see Mortensen (1927), D'yakonov (1967), Bernard (1979), Anisimova (1989), Smirnov \& Smirnov (1990), as well as Smirnov (1994).

Four of 10 brittle star species reported by Smirnov \& Smirnov (1990) to occur on the Laptev Sea shelf were recorded in the seabed photographs. Among these were the most abundant species listed by Smirnov \& Smirnov (1990) in their compilation of the results of Russian collections from 1901 to 1973 . Our study corroborates previous findings that brittle stars dominate the megabenthic communities in water depths of 30 to $60 \mathrm{~m}$ (Sirenko et al. 1995). They accounted for up to $>99 \%$ of the specimens visible on the photographs. Their share in the total number of megabenthic organisms (echinoderms, crustaceans, polychaetes and bivalves) in dredge catches ranged from nil to $60 \%$ (Schmid \& Petryashov unpubl.). Such a predominance of brittle stars was also recorded in other seabed imaging studies in Arctic waters (Piepenburg \& Schmid $1996 \mathrm{a}, \mathrm{b})$ and seems to be a common phenomenon of many polar shelf communities both in the Arctic (Zenkevitch 1963, Curtis 1975, Carey 1991) and Antarctica (Voß 1988, Dahm 1995).

\section{Standing stock}

The benthos of the high-Arctic Laptev Sea had been reported to be generally poor in terms of both diversity and standing stock compared to other Eurasian-Arctic shelf seas (Zenkevitch 1963, Golikov 1990). This scarcity was attributed to the most severe climate in the Laptev Sea, as well as to the very low salinities due to strong freshwater inflow. However, we recorded quite high megabenthic abundances on the Laptev Sea shelf, especially for the brittle stars Ophiocten sericeum and, though less pronounced, Ophiura sarsi. Very high densities of $O$. sericeum (up to $>500$ ind. $\mathrm{m}^{-2}$ ) were locally found on the flanks of the shelf valleys, being similar to maximum values reported for $O$. sericeum from shoals in the Barents Sea (about 500 ind. $\mathrm{m}^{-2}$; Piepenburg \& Schmid 1996a) or the Belgica Bank off Northeast Greenland (about 330 ind. $\mathrm{m}^{-2}$; Piepenburg \& Schmid 1996b). The maximum brittle star biomass values were not lower in the Laptev Sea either: $>3.5 \mathrm{~g} \mathrm{AFDM} \mathrm{m}^{-2}$ in the Laptev Sea, about $5 \mathrm{~g}$ AFDM $\mathrm{m}^{-2}$ in the Barents Sea (Piepenburg \& Schmid 1996a), and about $2 \mathrm{~g} \mathrm{AFDM} \mathrm{\textrm {m } ^ { - 2 }}$ off Northeast Greenland (Piepenburg \& Schmid 1996b).

The standing stock figures recorded at these Arctic sites were not much lower than those observed for both 
endobenthic amphiurids and epibenthic Ophiura species on boreal shelves (Muus 1981, Salzwedel et al. 1985). They are comparable to abundances of dense bathyal brittle star populations that were reported by imaging inventories of e.g. Ophiophthalmus normani from $1300 \mathrm{~m}$ off California, USA (16 ind. $\mathrm{m}^{-2}$; Smith \& Hamilton 1983), Ophiacantha fidelis from $450 \mathrm{~m}$ off Tasmania, Australia (350 ind. $\mathrm{m}^{-2}$ : Blaber et al. 1987), as well as Ophiura sarsi from $280 \mathrm{~m}$ off Japan (370 ind. $\mathrm{m}^{-2}$; Fujita \& Ohta 1989) and $500 \mathrm{~m}$ off South Carolina, USA (>30 ind. $\mathrm{m}^{-2}$; Stancyk et al. 1994).

The input of organic carbon to the benthic systems must be sufficient to sustain these high brittle star densities. Primary production in the euphotic zone and food supply to the benthos is ultimately controlled by hydrodynamics and, in polar waters, ice cover (Grebmeier \& Barry 1991, Graf 1992). In the Laptev Sea, the following features may lead to an enhanced pelagic production and/or flow of organic matter to the seabed. Firstly, marginal ice zones (MIZ) are well known as sites of locally and temporally enhanced production in ice-covered seas (Slagstad 1985, Sakshaug \& Skjoldal 1989). In particular 'seasonally receding ice edges', as they are also found in the Laptev Sea (Timokhov 1994), provide favourable conditions for rapid diatom blooms (Rey \& Loeng 1985). A large amount of the organic matter produced in the MIZ sinks out of the euphotic layer in pulsed sedimentation events (Hebbeln \& Wefer 1991, Andreassen et al. 1996) and is, thus, available to the benthos. Secondly, polynyas, permanent or recurrent ice-free areas in the pack ice zone, have been identified to be of special importance for physical and ecological processes of polar waters (Stirling 1980). A narrow flaw lead or polynya along the border of the coastal fast ice is a characteristic feature of the sea ice cover of the Laptev Sea in winter and spring (Dethleff 1994, Timokhov 1994, Gukov 1995). Compared to the surrounding ice-covered areas, pelagic production is often relatively high in polynya regions (Gradinger \& Baumann 1991), and pronounced mesoscale gradients characterize their hydrographic regimes (Schneider \& Budéus 1994). Field studies in the Northeast Water Polynya off Northeast Greenland have provided evidence for a tight benthic-pelagic coupling (Piepenburg et al. in press). Hobson et al. (1995) concluded from isotopic studies that fresh ungrazed organic carbon apparently reaches the seabed below the polynya, and benthic biomass was reported to be considerably enhanced (Ambrose \& Renaud 1995). Grebmeier (1993) described a similar pattern for an area in the Bering Sea influenced by the St. Lawrence Island polynya in winter/spring. For the Laptev Sea, Gukov (1995) reported evidence that benthic standing stock is positively affected by the Lena polynya. Thirdly, allochthonous organic matter im- ported from more productive areas or from terrestrial ecosystems was shown to be an additional major food source of benthic communities, particularly in barren Arctic seas (Grebmeier 1993, Feder et al. 1994). This source may be quite important for the Laptev Sea, which is heavily affected by fluvial inflow (Timokhov 1994). Cauwet \& Sidorov (1996) estimated that the Lena discharges about $5.3 \times 10^{6}$ tons of total organic carbon $\mathrm{yr}^{-1}$, most of it during the flood period in June/ July.

Besides food supply, biotic interactions may control the standing stock of epibenthic organisms. Based on paleoecological evidence, Aronson \& Sues (1987) argued that brittle star populations are primarily affected by predation. If predation pressure is low, as it can be generally assumed to have been before the evolution of modern fish, dense beds of epibenthic brittle stars can exist. This hypothesis implies that predation pressure on epibenthic brittle stars is rather low at present, both in bathyal zones and on Arctic shelves from which high abundances have been reported.

\section{Organic carbon demand}

The amount of organic carbon consumed by the populations of 3 selected brittle star species does not depend primarily on their standing stock but on their respiration, production and assimilation efficiency. Their population respiration was estimated using an allometric relationship between body mass and individual respiration rates (Mahaut et al. 1995). For 18 specimens from 2 of 3 species, Schmid (1996) published individual oxygen consumption values which could have been used instead. However, the body mass of the animals covered by these measurements encompassed only a small part of the range of the specimens recorded on the seabed photographs in the Laptev Sea $(12$ to $60 \mathrm{mg}$ AFDM vs $<1$ to $300 \mathrm{mg}$ AFDM). Therefore, we preferred to apply the equation of Mahaut et al. (1995) which allowed for taking the size dependence of individual respiration rates into account. For specimens of the same mass, the values estimated by this approach were quite close to those measured by Schmid (1996), being 50\% higher and $100 \%$ lower at maximum (with an average of $20 \%$ lower for both species). Production of brittle stars was approximated from respiration values using a constant net growth efficiency $K_{2}$ of 0.3 , which has been recommended as grand average for poikilothermic wild populations from boreal regions (Wieser 1986, McLusky \& MacIntyre 1988). However, for polar invertebrates $K_{2}$ may be higher than $30 \%$ because temperature may be less important in limiting benthic production than in controlling respiration (Emerson 
1989). Therefore, our estimates of production and, hence, also organic carbon demand can be assumed to be rather conservative

For the Laptev Sea, no data on primary production and vertical particle flux are yet available. Generally, the Eurasian-Arctic marginal seas (Kara, Laptev, East Siberian and Beaufort Seas), being ice-covered for 8 to 10 months each year, are believed to be characterized by comparatively low rates of pelagic primary production. Anderson et al. (1990) estimated that total new production over the Eurasian-Arctic shelves averages $45 \mathrm{~g} \mathrm{C} \mathrm{m}^{-2} \mathrm{yr}^{-1}$. Phytoplankton production estimates range from 10 to $25 \mathrm{~g} \mathrm{C} \mathrm{m}^{-2} \mathrm{yr}^{-1}$, most of it built up during the short ( 1 to $4 \mathrm{mo}$ ) periods of open water. During the time of ice cover, sea-ice algae might contribute an additional 1 to $5 \mathrm{~g} \mathrm{C} \mathrm{m}^{-2} \mathrm{yr}^{-1}$ (Moritz et al. 1990). Legendre et al. (1992) suggested a value of $37 \mathrm{~g} \mathrm{C} \mathrm{m}^{-2}$ $\mathrm{yr}^{-1}$ (combining $27 \mathrm{~g} \mathrm{C} \mathrm{m}^{-2} \mathrm{yr}^{-1}$ by phytoplankton plus $10 \mathrm{~g} \mathrm{C} \mathrm{m}^{-2} \mathrm{yr}^{-1}$ by sympagic algae in first-year ice) as gross average microalgal production in Arctic shelf regions. Only a part of the organic matter produced and suspended in the water column eventually reaches the seabed. In the high-Arctic northern Barents Sea in July 1991. Andreassen et al. (1996) recorded a high variability of the sedimented matter in composition, quality and quantity, primarily related to ice cover, hydrography and zooplankton grazing. From a station in the seasonally ice-covered zone of this region, which can best be compared to the Laptev Sea in its environmental conditions, they reported a vertical particle flux of about $50 \mathrm{mg}$ POC m $\mathrm{m}^{-2} \mathrm{~d}^{-1}$ in $60 \mathrm{~m}$ depth. In a model of the particulate carbon flux dynamics in the Barents Sea, Wassmann \& Slagstad (1993) estimated an annual sedimentation of $9 \mathrm{~g} \mathrm{POC} \mathrm{m} \mathrm{Pr}^{-1}$ for the high-Arctic northern region. Sedimentation varied substantially among years in relation to ice cover dynamics, but was in any case essentially confined to the $4 \mathrm{mo}$ period June-September (during which the average daily sedimentation rate was, thus, about $70 \mathrm{mg} P O C \mathrm{~m}^{-2} \mathrm{~d}^{-1}$ )

In an attempt to relate our megabenthic carbon demand estimates to the potential carbon supply, we generally assume that primary production and sedimentation are (1) lower than average in the Laptev Sea if compared to other Eurasian-Arctic shelves and (2) virtually nil before and after the 4 mo ice-free period of mid-June to mid-October. During this interval, the average daily primary production is supposed to be about $150 \mathrm{mg} \mathrm{C} \mathrm{m}{ }^{-2} \mathrm{~d}^{-1}$ (equivalent to an annual production of about $20 \mathrm{~g} \mathrm{C} \mathrm{m}^{-2} \mathrm{yr}^{-1}$ ) and the average vertical particle flux to the seabed to be about $50 \mathrm{mg}$ POC $\mathrm{m}^{-2} \mathrm{~d}^{-1}$ (equivalent to an annual sedimentation of about $6 \mathrm{~g} \mathrm{C} \mathrm{m}^{-2} \mathrm{yr}^{-1}$ ). Given these assumptions, our data on the organic carbon demand (Table 3) suggest that epibenthic brittle star populations consume $<1$ to $7 \%$ of the autochthonous primary production and $<1$ to
$20 \%$ of the sedimented POC during an average day between mid-June and mid-October. It should be noted, however, that allochthonous carbon sources which might be particularly important in the Laptev Sea are not considered in such a budget. For comparison: Dahm (1995) estimated that dense Antarctic brittle star assemblages may consume, on a yearly basis, 5 to $20 \%$ of the organic carbon supplied by the vertical particle flux. Though our consumption figures are based on numerous assumptions and certainly represent gross estimates only, they indicate that the locally abundant epibenthic brittle stars may contribute substantially to the cycling of organic matter in the Laptev Sea.

\section{Conclusions}

The standing stock of the epibenthic megafauna of the Laptev Sea shelf was found to be not lower than in other Arctic seas, at least in the deeper shelf valleys that are not subject to reduced and probably fluctuating salinities. Together, the data from this study in the Laptev Sea and from investigations in other Arctic shelf regions (Greenland Sea, Barents Sea) indicate that brittle stars can reach high abundances and strongly dominate the epibenthic communities of highlatitude shelves. Gross estimates of brittle star respiration, production and organic carbon demand suggest that a substantial portion of the energy and carbon flow in Arctic shelf ecosystems is channelled through these dense assemblages.

Acknowledgements. We thank the captains and crews of the Russian vessels 'Ivan Kireyev' and 'Kapitan Dranitsyn' as well as the participants of the TRANSDRIFT I and III expeditions in 1993 and 1995, respectively, for their help during the cruises. Thanks also to Frank Lindemann (Kiel) for sedimentological data, as well as to I. S. Smirnov and V. V. Petryashov (St. Petersburg) for taxonomic advice. Furthermore, we acknowledge the constructive comments on the manuscript provided by several colleagues from the Institute for Polar Ecology (Kiel), as well as by 4 anonymous reviewers. Our study is a contribution to the interdisciplinary Russian-German project 'Laptev Sea System' It was supported by grant 03PL009A of the German Federal Ministry of Research and Technology to Michael Spindler (Kiel).

\section{LITERATURE CITED}

Ambrose WG, Renaud PE (1995) Benthic response to water column productivity patterns: evidence for benthicpelagic coupling in the Northeast Water Polynya. J Geophys Res 100:4411-4421

Anderson LG, Dyrssen D, Jones EP (1990) An assessment of the transport of atmospheric $\mathrm{CO}_{2}$ into the Arctic Ocean $\mathrm{J}$ Geophys Res 95:1703-1712

Andreassen I, Nöthig EM, Wassmann P (1996) Vertical particle flux on the shelf off northern Spitsbergen, Norway. Mar Ecol Prog Ser 137:215-228 
Anisimova NA (1989) Distribution patterns of echinoderms in the Eurasian sector of the Arctic Ocean. In: Herman Y (ed) The Arctic seas. Van Nostrand, New York, p 281-301

Aronson RB, Sues HD (1987) The paleoecological significance of an anachronistic community. In: Kerfoot WC, Sih A (eds) Predation: direct and indirect impacts on aquatic communities. University Press of New England, Hanover, p $355-366$

Bernard FR (1979) Bivalve mollusks of the western Beaufort Sea. Contrib Sci (Los Angel) 313:1-80

Blaber SJM, May NJ, Young JW, Bulman CM (1987) Population density and predators of Ophiacantha fidelis (Koehler, 1930) (Echinodermata: Ophiuroidea) on the continental slope of Tasmania. Austr J Mar Freshwat Res 38:243-247

Carey AG (1991) Ecology of the North American Arctic continental shelf benthos: a review. Cont Shelf Res 11:865-883

Cauwet G, Sidorov I (1996) The biogeochemistry of Lena River: organic carbon and nutrients distribution. Mar Chem 53:211-227

Curtis MA (1975) The marine benthos of Arctic and subArctic continental shelves. Polar Rec 17:595-626

Dahm C (1995) Ökologie und Populationsdynamik antarktischer Ophiuroiden (Echinodermata). PhD thesis, University of Bremen

Dayton PK (1990) Polar benthos. In: Smith WO (ed) Polar oceanography, Part B: Chemistry, biology and geology. Academic Press, London, p 631-685

Dethleff D (1994) Dynamics of the Laptev Sea flaw lead. In: Kassens H, Hubberten HW, Pryamikov SM, Stein R (eds) Russian-German cooperation in the Siberian shelf seas: geo-system Laptev Sea. Ber Polarforsch 144:49-54

D'yakonov AM (1967) Ophiuroids of the USSR Seas. In: Strelkov AA (ed) Keys to the Fauna of the USSR, Zool Inst Acad Sci USSR, No. 55. Israel Program for Scientific Translations, Jerusalem, p 1-122 (translated from Russian)

Emerson CW (1989) Wind stress limitation of benthic secondary production in shallow, soft-sediment communities. Mar Ecol Prog Ser 53:65-77

Feder HM, Naidu AS, Jewett SC, Hameedi JM, Johnson WR, Whitledge TE (1994) The northeastern Chukchi Sea: benthos-environmental interactions. Mar Ecol Prog Ser 111: $171-190$

Fujita T, Ohta S (1989) Spatial structure within a dense bed of the brittle star Ophiura sarsi (Ophiuroidea: Echinodermata) in the bathyal zone of Otsuchi, Northeastern Japan. J Oceanogr Soc Japan 45:289-300

Gage JD, Tyler PA. (1991.) Deep-sea biology: a natural history of organisms at the deep sea floor Cambridge University Press, Cambridge

Golikov AN (ed) (1990) Ecosystems of the New Siberian shoals and fauna of the Laptev Sea and adjacent waters of the Arctic Ocean. Explorations of the fauna of the seas, Vol 37(45). Nauka, Leningrad (in Russian)

Gordeev VV, Sidorov IS (1993) Concentrations of major elements and their outflow into the Laptev Sea by the Lena River. Mar Chem 43:33-45

Gradinger RR, Baumann MEM (1991) Distribution of phytoplankton communities in relation to the large-scale hydrographical regime in the Fram Strait. Mar Biol 111:311-321

Graf G (1992) Benthic-pelagic coupling: a benthic view Oceanogr Mar Biol Ann Rev 30:149-190

Grebmeier JM (1993) Studies of pelagic-benthic coupling extended onto the Soviet continental shelf in the northern Bering and Chukchi seas. Cont Shelf Res 13:653-668

Grebmeier JM, Barry JP (1991) The influence of oceanographic processes on pelagic-benthic coupling in polar regions: a benthic perspective. J Mar Syst 2:495-518
Gukov AY (1995) Hydrobiological research in the Lena polynya. In: Kassens H, Piepenburg D, Thiede J, Timokhov L. Hubberten HW, Priamikov SM (eds) Russian-German cooperation: Laptev Sea System. Ber Polarforsch 176 : $228-229$

Haedrich RL, Rowe GT, Polloni PT (1980) The megabenthic fauna in the deep sea south of New England, USA. Mar Biol 57:165-179

Hebbeln D, Wefer G (1991) Effects of ice coverage and icerafted material on sedimentation in the Fram Strait. Nature 350:409-411

Hempel $G$ (1985) On the biology of polar seas, particularly the Southern Ocean. In: Gray JS, Christiansen ME (eds) Marine biology of polar regions and the effect of stress on marine organisms. John Wiley \& Sons, Chichester, p 3-34

Hobson KA, Ambrose WG, Renaud PE (1995) Sources of primary production, benthic-pelagic coupling, and trophic relationships within the Northeast Water Polynya: insights from $\partial^{i 3} \mathrm{C}$ and $\partial^{15} \mathrm{~N}$ analysis. Mar Ecol Prog Ser 128:1-10

Holme NA, McIntyre AD (1984) Methods for study of the marine benthos. Blackwell Scientific Publications, Oxford

Kassens H (ed) (1995) Laptev Sea System: expeditions in 1994. Ber Polarforsch 182:1-195

Kassens H (ed) (in press) Russian-German cooperation: the TRANSDRIFT III expedition to the Laptev Sea in 1995. Ber Polarforsch

Kassens H, Karpiy VY (eds) (1994) Russian-German cooperation: the TRANSDRIFT I expedition to the Laptev Sea. Ber Polarforsch 151:1-168

Knickmeier K, Schmid MK (1994) Ecological studies in the Laptev Sea. In: Kassens H, Karpiy VY (eds) Russian-German cooperation: the TRANSDRIFT I expedition to the Laptev Sea. Ber Polarforsch 151:59-61

Lampitt RS, Billet DSM, Rice AL (1986) Biomass of the invertebrate megabenthos from 500 to $4100 \mathrm{~m}$ in the northeast Atlantic. Mar Biol 93:69-81

Legendre L, Ackley SF, Dieckmann GS, Gulliksen B, Horner R, Hoshiai T, Melnikov IA, Reeburgh WS, Spindler M, Sullivan CW (1992) Ecology of sea ice biota: 2. Global significance. Polar Biol 12:429-444

Lindemann F (1994) Sonographische und sedimentologische Untersuchungen in der Laptevsee, sibirische Arktis. Dipl thesis, Kiel University

Mahaut ML, Sibuet M, Shirayama Y (1995) Weight-dependent respiration rates in deep-sea organisms. Deep Sea Res 42:1575-1582

McLusky DS, MacIntyre AD (1988) Characteristics of the benthic fauna. In: Postma $\mathrm{H}$, Zijlstra JJ (eds) Ecosystems of the world 27: continental shelves. Elsevier, New York, p $131-154$

Moritz RE, Aagaard K, Baker DJ, Codispoti LA, Smith SL, Smith WO, Tipper RC. Walsh JE (eds) (1990) Arctic system science: ocean-atmosphere-ice interactions. Joint Oceanographic Institutions, Washington, DC

Mortensen T (1927) Handbook of the echinoderms of the British Isles. Oxford University Press, Edinburgh

Muus K (1981) Density and growth of juvenile Amphiura filiformis (Ophiuroidea) in the Oresund. Ophelia 20:153-168

Ockelmann WK (1958) The zoology of East Greenland: marine Lamellibranchiata. Meddr Gronland 122(4):1-256

Paterson GLJ (1985) The deep-sea Ophiuroidea of the North Atlantic Ocean. Bull Br Mus Nat Hist (Zool) 49:1-162

Petryashov VV (1994) Hydrobiological investigations in the Laptev Sea. In: Kassens H, Karpiy VY (eds) Russian-German cooperation: the TRANSDRIFT I expedition to the Laptev Sea. Ber Polarforsch 151:54-59 
Piepenburg D (1995) 'Glasnost' in der arktischen Benthosforschung: politisches Tauwetter im sibirischen Nordpolarmeer In: Hempel I, Hempel G (eds) Biologie der Polarmeere. Gustav Fischer Verlag, Jena, p 240-247

Piepenburg D, Ambrose WG, Brandt A, Renaud PE, Ahrens $M J$, Jensen $P$ (in press) Benthic community patterns reflect water column processes in the Northeast Water polynya (Greenland). J Mar Syst

Piepenburg D, Blackburn TH, von Dorrien CF, Gutt J, Hall POJ, Hulth S, Kendall MA, Opalınski KW, Rachor E, Schmid MK (1995) Partitioning of benthic community respiration in the Arctic (northwestern Barents Sea). Mar Ecol Prog Ser 118:199-213

Piepenburg D, Schmid MK (1996a) Brittle star fauna (Echinodermata: Ophiuroidea) of the Arctic northwestern Barents Sea: composition, abundance, biomass and spatial distribution, Polar Biol 16:383-392

Piepenburg D, Schmid MK (1996b) Distribution, abundance, biomass, and mineralization potential of the epibenthic megafauna of the Northeast Greenland shelf. Mar Biol 125:321-332

Piepenburg D, von Juterzenka K (1994) Abundance, biomass and spatial distribution patterns of brittle stars (Echinodermata: Ophiuroidea) on the Kolbeinsey Ridge north of Iceland. Polar Biol 14:185-194

Rey $F$, Loeng $\mathrm{H}$ (1985) The influence of ice and hydrographic conditions on the development of phytoplankton in the Barents Sea. In: Gray JS, Christiansen ME (eds) Marine biology of polar regions and effects of stress on marine organisms. Wiley and Sons, Chichester, p 49-63

Rice AL, Aldred RG, Darlington E, Wild RA (1982) The quantitative estimation of the deep-sea megabenthos: a new approach to an old problem. Oceanol Acta 5:63-72

Romero-Wetzel M. Gerlach S (1991) Abundance, bromass, size distribution and bioturbation potential of deep-sea macrozoobenthos on the Voring Plateau $(1200-1500 \mathrm{~m}$, Norwegian Sea). Meeresforsch 33:247-265

Sakshaug E, Skjoldal HR (1989) Life at the ice edge. Ambio 18:60-67

Salzwedel H, Rachor E, Gerdes D (1985) Benthic macrofauna communities in the German Bight. Veröff Inst Meeresforsch Bremerhaven 20:199-267

Schmid MK (1996) Zur Verbreitung und Respiration ökologisch wichtiger Bodentiere in den Gewässern um Svalbard (Arktis). Ber Polarforsch 202:1-92

Schneider DC, Gagnon JM, Gilkinson KD (1987) Patchiness of epibenthic megafauna on the outer Grand Banks of Newfoundland. Mar Ecol Prog Ser 39:1-13

Schneider W, Budéus G (1994) The North East Water polynya (Greenland Sea): I. A physical concept of its generation. Polar Biol 14:1-9

Sirenko BI, Petryashov VV, Rachor E, Hinz K (1995) Bottom biocoenoses of the Laptev Sea and adjacent areas. In: Kassens $\mathrm{H}$, Piepenburg D, Thiede J, Timokhov L, Hubberten HW, Priamikov SM (eds) Russian-German cooperation: Laptev Sea System. Ber Polarforsch 176:211-221

Sirenko BI, Piepenburg D (1994) Current knowledge on bicdiversity and benthic zonation patterns of Eurasian Arctic shelf seas, with special reference to the Laptev Sea. In: Kassens H, Hubberten HW, Pryamikov SM, Stein R (eds) Russian-German cooperation in the Siberian shelf seas: geo-system Laptev Sea. Ber Polarforsch 144:69-77
Slagstad D (1985) A model of phytoplankton in the marginal ice zone of the Barents Sea. In: Gray JS, Christiansen ME (eds) Marine biology of polar regions and effects of stress on marine organisms. Wiley and Sons, Chichester, p $35-48$

Smirnov AV (1994) Arctic echinoderms: composition, distribution and history of the fauna. In. David B, Guille A, Féral JP, Roux M (eds) Echinoderms through time (Echinoderms Dijon). Balkema, Rotterdam, p 135-143

Smirnov AV, Smirnov IS (1990) Echinoderms from the Laptev Sea. In: Golikov AN (ed) Ecosystems of the New Siberıan shoals and fauna of the Laptev Sea and adjacent waters of the Arctic Ocean. Nauka, Leningrad, p 411-462 (in Russian with English summary)

Smith CR, Hamilton SC (1983) Epibenthic megafauna of a bathyal basin off southern California: patterns of abundance, biomass, and dispersion. Deep Sea Res 30:907-928

Smith KL, Kaufmann RS, Wakefield WW (1993) Mobile megafaunal activity monitored with a time-lapse camera in the abyssal North Pacific. Deep Sea Res 40:2307-2324

Stancyk SE, Feller RJ, Aronson RB, Dobson WE, McKenzie JD (1994) Predation and regeneration of Ophiura sarsi on the US continental slope: use of a manned submersible to perform in situ experiments. In: David B, Guille A, Féral JP, Roux $M$ (eds) Echinoderms through time (Echinoderms Dijon). Balkema, Rotterdam. p 490

Stirling l (1980) The biological importance of polynyas in the Canadian Arctic. Arctic 33:303-315

Thuede J, Kassens H (1994) Prologue and scientific perspectives for the project 'Laptev Sea System' In: Kassens $H$, Hubberten HW, Pryamikov SM, Stein R (eds) RussianGerman cooperation in the Siberian shelf seas: geo-system Laptev Sea. Ber Polarforsch 144:VII-IX

Thurston MH, Bett, BJ, Rice AL, Jackson PAB (1994) Variations in the invertebrate abyssal megafauna in the North Atlantic Ocean. Deep Sea Res 41:1321-1348

Timokhov LA (1994) Regional characteristics of the Laptev and the East Siberian seas: climate, topography, ice phases, thermohaline regime, circulation. In: Kassens $H$, Hubberten HW, Pryamikov SM, Stein R (eds) RussianGerman cooperation in the Siberian shelf seas: geo-system Laptev Sea. Ber Polarforsch 144:15-31

Tyler PA, Gage JD (1982) The reproductive biology of Ophiacantha bidentata (Echinodermata: Ophiuroidea) from the Rockall Trough. J Mar Biol Ass UK 62:45-55

Voß J (1988) Zoogeographie und Gemeinschaftsanalyse des Makrozoobenthos des Weddellmeeres (Antarktis). Ber Polarforsch 45:1-145

Warner G (1982) Food and feeding mechanisms: Ophiuroidea. In: Jangoux M, Lawrence JM (eds) Echinoderm nutrition. Balkema, Rotterdam, p 161-181

Wassmann P. Slagstad D (1993) Seasonal and annual dynamics of particulate carbon flux in the Barents Sea. A model approach. Polar Biol 13:363-372

Wieser W (1986) Bioenergetik. Thieme, Stuttgart

Winberg GG (1960) Rate of metabolism and food requirements of fishes. Fish Res Bd Can Transl Ser 194:1-253 (translated from Russian)

Zar JH (1984) Biostatistical analysis. Prentice-Hall, Englewood Cliffs, NJ

Zenkevitch L (1963) Biology of the seas of the USSR. Allen \& Unwin, London 